Volume 3, Issue 1 (Winter 2011)

\title{
Jan van Eyck's Dresden Triptych: new evidence for the Giustiniani of Genoa in the Borromei ledger for Bruges, 1438
}

Noëlle L.W. Streeton

Recommended Citation:

Noëlle L.W. Streeton, “Jan van Eyck's Dresden Triptych: New Evidence for the Giustiniani of Genoa in the Borromei Ledger for Bruges, 1438," JHNA 3:1 (Winter 2011), DOI: 10.5092/ jhna.2011.3.1.1

Available at https://jhna.org/articles/jan-van-eycks-dresden-triptych-new-evidence-giustiniani-of-genoa-borromei-ledger-bruges/

Published by Historians of Netherlandish Art: https://hnanews.org/

Republication Guidelines: https://jhna.org/republication-guidelines/

Notes: This PDF is provided for reference purposes only and may not contain all the functionality or features of the original, online publication. This is a revised PDF that may contain different page numbers from the previous version. Use electronic searching to locate passages. This PDF provides paragraph numbers as well as page numbers for citation purposes.

ISSN: $1949-9833$ 


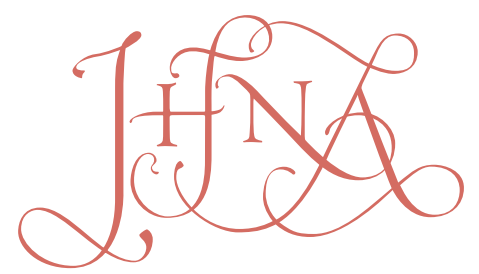

\section{JAN VAN EYCK'S DRESDEN TRIPTYCH: NEW EVIDENCE FOR THE GIUSTINIANI OF GENOA IN THE BORROMEI LEDGER FOR BRUGES, 1438}

\section{Noëlle L.W. Streeton}

Ledgers from the Milanese bank Filippo Borromei and Company of Bruges and London have been transcribed by James Bolton and Francesco Guidi Bruscoli as part of the Borromei Research Project at Queen Mary, University of London. The ledger for Bruges, dated 1438, offers information about the financial activities of the Giustiniani family of Genoa and names Raffaello Giustiniani as the member of the family based in Bruges. This article explores the context of this new piece of evidence, which offers a fresh perspective on the potential connection between this Genoese family and the Bruges workshop of Jan van Eyck. 10.5092/jhna.2011.3.1.1

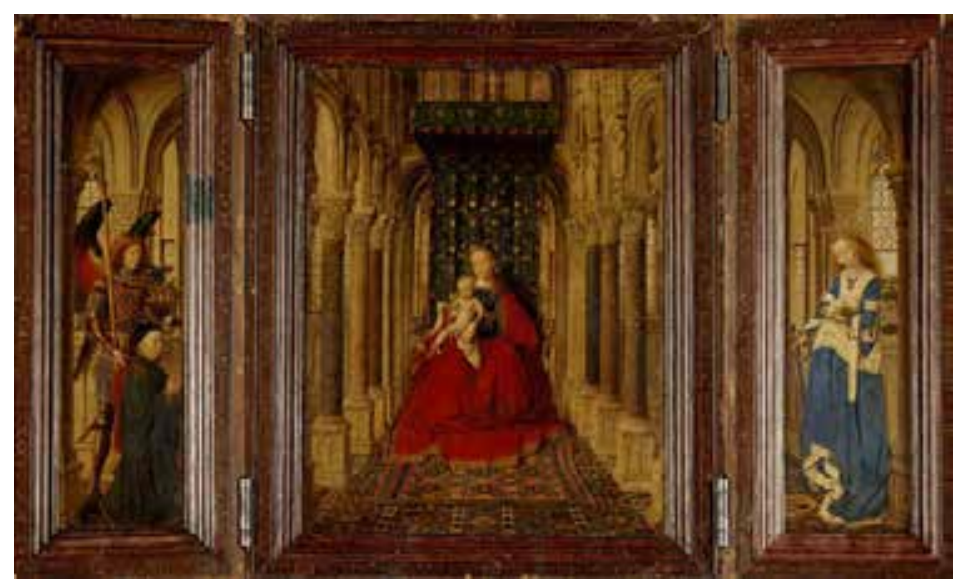

Fig. 1 Jan van Eyck, Virgin and Child with Saints Catherine and Michael and a Donor (the Dresden or Giustiniani Triptych), 1437, oil on oak panel, $33.1 \times 27.5 \mathrm{~cm}$ (center panel), $33.3 \times 13.6 \mathrm{~cm}$ (wings). Staatliche Kunstsammlungen, Dresden, Gemäldegalerie Alte Meister, inv. no. 799 (artwork in the public domain)

7 he Virgin and Child with Saints Catherine and Michael and a Donor in Dresden is the only surviving triptych identified with Jan van Eyck (ca. 1390-1441)(fig. 1). The altarpiece measures $33 \times 27.5 \times 5 \mathrm{~cm}$ when the wings are folded to enclose the central panel (fig. 2). The central frame bears the painter's signature, his device, ALC IXH XAN ("as well as I can"), and the year of completion, 1437. The frames of the wings are distinguished by two coats of arms, one of which is associated with the Giustiniani family of Genoa (fig. 3). Since the mid-nineteenth century, German scholars have consistently tried to clarify the relationship between the coats of 


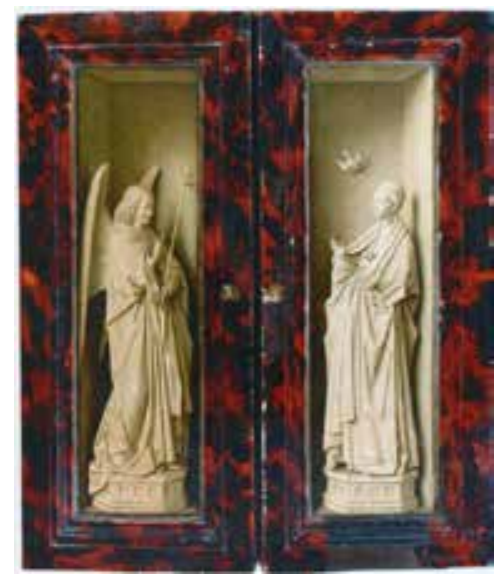

Fig. 2 The Dresden Triptych shown closed, displaying The Annunciation on the exterior of the wings.
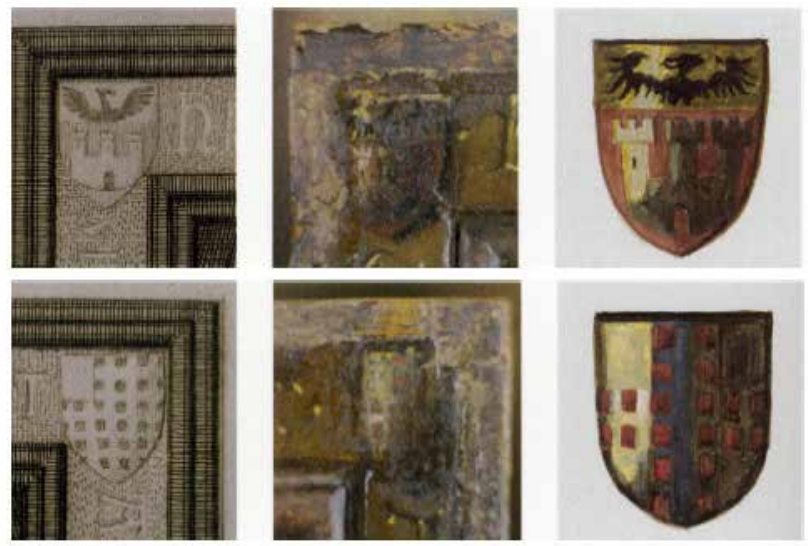

Fig. 3 A coat of arms was painted onto the upper corner of each wing frame. Hugo Bürkner's drawings (far left top and bottom) are shown here alongside Christoph Schölzel's recent macrophotographs and scale drawings (see Bürkner, Die Dresdener Gemälde-Gallerie, and Schölzel's drawings in Neidhardt and Schölzel, Das Geheimnis des Jan van Eyck, p. 180).

arms and the image of the donor in the left-hand panel. ${ }^{1} \mathrm{He}$ is portrayed in a fashionable green houppelande with a red hood, kneeling directly in front of the Archangel Michael. To date, researchers continue to search for evidence that can connect the commission with the mercantile activities of the Giustiniani. In advance of the most recent contributions to scholarship on the triptych in 2000 and 2005, Uta Neidhardt and Christoph Schölzel guessed that the key to the donor's identity lay in as-yet unexamined archival evidence. ${ }^{2}$ They asked "Who was the donor of the Dresden altarpiece?" and went on to state that "The question is still not answered, since nothing said previously can make concrete the identity of the man who is represented. In the end we come back to the coat of arms, which is part of the original frame. Returning to the thesis of the Giustiniani as the merchant family who gave the commission is, however, impossible without further information....[I]t is undoubtedly only a matter of time until this purely archival problem is resolved."

This "archival problem" is one faced by all historians of early Netherlandish painting, primarily because vast quantities of objects and their associated documentation have been dispersed and/ or destroyed. ${ }^{4}$ However, the recent transcription of a Bruges ledger for the Milanese bank Filippo Borromei and Company offers promising new information. ${ }^{5}$ The ledger for 1438 records a range of transactions that refer directly to the Giustiniani family of Genoa, and, significantly, this ledger contains one entry that singles out a particular member of the family. An entry dated August 25, 1438, refers directly to Raffaello Giustiniani "of Bruges."

3 This article sets out the scholarly debates that have surrounded the Dresden Triptych before exploring the possibility that the Borromei ledger offers a plausible identity for a person involved in the commission. It begins with a brief discussion of the known provenance and scholarship related to the altarpiece before considering the evidence in the Borromei ledger in the context of contemporary events in the Burgundian Netherlands. ${ }^{7}$ The Borromei accounts point directly to the Giustiniani circle active in Bruges and perhaps indirectly to a connection between this Genoese family and the Bruges workshop of Jan van Eyck. 


\section{Historical Debates}

The Dresden Triptych is thought to be one of the two items sent to Vincenzo I Gonzaga by his agent, Lodovico Cremasco, from Rome on May 10, 1597; and an altarpiece matching its description was recorded in an inventory of the Gonzaga collection on its sale to Charles I of England thirty years later. ${ }^{8}$ While the triptych was part of the English royal collection, the collector's mark of Charles I was placed on the outer edge of the right-hand wing and after the regicide and dispersal of the collection, the painting eventually came into the possession of the Saxon Electors. It was first recorded in Dresden in 1754 as a work by Albrecht Dürer, an attribution that continued to be accepted until the Berlin archaeologist/historian Aloys Hirt reattributed it to van Eyck in $1830 .{ }^{9}$ In the 1840s, the Dresden painter Eduard Bendemann was tasked with reconstructing at least three areas of loss in the Virgin's gown, ${ }^{10}$ and it is likely that a temporary ebony frame was attached at this time (1844). ${ }^{11}$

5 The temporary frame appears to have been designed to protect the marbling of the original frames and their inscriptions, which imitate precious gold work. These were not concealed by the ebony frame, thus allowing Max Friedländer to describe the texts when he began to publish the fourteen volumes of Die altniederländische Malerei in 1924. The outer frame of the central panel bears the text: "Hec est speciosor sole et sup(er) o(mn)em stellaru(m) dispositionem..." (She is more beautiful than the sun, and above all the order of the stars...) from the Book of Wisdom/ Song of Solomon, lines that also appear in the inscriptions on the Virgin in the Ghent Altarpiece and on the frame of the Van der Paele Madonna. ${ }^{12}$ On the wing with Saint Catherine can be read the words "Virgo prudens anelavit ad sedem siderea $(\mathrm{m})$..." (The prudent virgin has longed for the starry throne...), a text that is derived from the liturgy for the service of vespers on November 25 , this saint's name day. The text on the donor wing comes from the Roman breviary for the Dedication Feast of Saint Michael: "Hic est archangelus princeps milici(a)e angelorum..." (This is Michael the Archangel, leader of the angelic hosts...). According to Carol Purtle, each of these texts was in contemporary use at Saint Donatian's in Bruges. ${ }^{13}$

6 The coats of arms were also evidently not covered by the lip of the temporary frame because in 1863 Hugo Bürkner published drawings of them in his catalogue for the Gemäldegalerie in Dresden. ${ }^{14}$ Since this time, many scholars have searched for a connection between the the Giustiniani arms on the frame and the identity of the donor. Ludwig Kaemmerer was the first to claim, at the end of the nineteenth century, that the donor was "a Michel Giustiniani, son of Marco, [who] lived from 1400," a supposition echoed by W. H. James Weale. ${ }^{15}$ August Schmarsow went a step further, linking the triptych to Genoa and dating it to 1427, when he maintained that van Eyck traveled there. ${ }^{16} \mathrm{He}$ also stated that "the first documentary evidence of a Michele Giustiniani in Genoa dates to the beginning of the [twentieth] century," although he did not specify the nature of this evidence or its source. ${ }^{17}$ The same potentially relevant link between the donor and the saint standing at his shoulder was referred to by Roberto Weiss in his 1956 article "Jan van Eyck and the Italians." Weiss cited a petition in the State Archives in Genoa, which was filed in 1430 by a Michele Giustiniani, requesting permission to live in Genoa. ${ }^{18}$ From this, Weiss deduced that the man had been born and brought up in Bruges and was therefore most likely the donor of the triptych, which he thought predated the petition. ${ }^{19}$ The proposition that this Michele was the donor does not preclude a later date for the painting, but it must be said that Weiss's proposal was 
stronger before the date 1437 was uncovered on the central frame in the late $1950 \mathrm{~s}^{20}$

7 While Schmarsow and Weiss considered the Dresden Triptych to date before 1430, and Friedländer could "unhesitatingly range it between the Arnolfini painting in London (1434) and the van der Paele altarpiece (1436)," ${ }^{21}$ questions about its date were finally answered in 1959 when the temporary frame and the dark brown paint on the inner molding of the central frame were removed. ${ }^{22}$ Given the early misidentification and ongoing questions over the triptych's date, it seems that portions of the frame had been covered with a uniform brown paint for centuries. But soon after the triptych was returned to Dresden from Moscow, where it was taken after the Second World War, the overpaint was removed to reveal van Eyck's name, a date, and his device: Johannes de eyck me fecit et c(o)mplevit Anno DmM-CCC-XXXVII.ALC.IXH·XAN. ${ }^{23}$ This express statement of a year of completion placed this triptych near the end of van Eyck's œuvre rather than somewhere in the middle. Even with this knowledge, the damaged state of the coats of arms has continued to frustrate efforts to establish a provenance.

8 With this problem in mind, Christoph Schölzel examined the panels and frames under a microscope in 1998, observing that the coats of arms, like the frame texts, appear to have been painted directly onto a brown-colored bole or ground. ${ }^{24} \mathrm{He}$ determined that the shields are "organically integrated" with the inscriptions and that they show the same type of highlights on the characters painted to look like embossed letters. To aid his examination, Schölzel prepared scale reconstructions, based on his own observations and on the drawings published in Bürkner (fig. 3). While the blazon on the Saint Catherine wing remains unidentified, that on the wing depicting the donor a castle with three towers surmounted by an eagle with outstretched wings - is undoubtedly that of the Giustiniani. Of course, Schölzel's observations cannot be confirmed without a paint sample to help establish whether or not a varnish or dirt layer exists between the marbling and the base tone used for the original coats of arms. Nonetheless, based on visible evidence in the painted surface and in areas of loss, Schölzel concluded that the coats of arms on both wing frames are contemporary with the painting. ${ }^{25}$

If the Giustiniani arms are, as seems likely, contemporary with the original composition, they can indeed be seen as a clue to the relationship between the image of the donor and the Giustiniani family of Genoa. However, it is still open to question whether Michele Giustiniani returned on occasion to Bruges and possibly commissioned the altarpiece during such a visit; whether he directed a family member to act on his behalf; or, alternatively, whether another individual altogether was responsible for the commission. Nothing substantive has been found to situate the activities of a Michele Giustiniani in Bruges after 1430, and while it is, at present, not possible to verify other proposals, it is worth considering the possibility that another member of the Genoese Giustiniani family who was resident in Bruges acted as an intermediary or commissioned the altarpiece for himself from Jan van Eyck.

\section{The Giustiniani of Genoa}

10 At least two lines of the Giustiniani family, including the Venetian and Genoese branches, were active in Bruges in the second quarter of the fifteenth century. ${ }^{26}$ The Giustiniani of Genoa can be traced to the traders who gained control of the island of Chios in 1346, when a flotilla led by Simon Vignoso conquered both the island and the port of Phokaea (Foça) on the mainland. ${ }^{27}$ 
The strategic location of Chios, en route to Constantinople, enabled the Genoese to compete with Venice for a share of trade in the Levant and Black Sea. The Republic of Genoa would not pay the traders for their victory, but on February 26, 1347, the republic granted them the revenues from Chios and Phokaea. ${ }^{28}$ This arrangement allowed the Giustiniani to manage the two territories directly and gather substantial income from their distribution of gum mastic and alum, which were shipped across Europe.

11 To manage Chios, twelve Genoese nobles formed a private trading society, which ultimately bound them into a financial and political "family." Nicolò de Caneto de Lavagna, Giovanni Campi, Francesco Arangio, Nicolò di S. Teodoro, Gabriele Adorno, Paolo Banca, Tommaso Longo, Andriolo Campi, Raffaello de Forneto, Luchino Negro, Pietro Oliverio, and Francesco Garibaldi adopted a coat of arms depicting a castle surmounted by an eagle. Significantly, too, they adopted the name Giustiniani, as if "they were born from the same father and the same mother," with a contract stipulating that this name would not be passed by right of birth from one generation to the next. ${ }^{29}$ Instead, each man's share in the mercantile society was transferable and could be sold, making this a republican nobility, as opposed to a feudal one. It is not clear when the name of the Genoese Giustiniani became, like that of the Venetian line, hereditary and dynastic, but by the late fifteenth century the Giustiniani of Genoa had acquired noble status and vast amounts of land in and around this international port.

12 One question that Neidhardt and Schölzel posed is whether there might be a connection between the Giustiniani and the Adornes, who had been established in Bruges since the second half of the thirteenth century. ${ }^{30}$ They noted that Jan Rotsaert had drawn connections between the Adornes and the Alexandrian princess Saint Catherine, who was legendary for her learning and was the patron saint of theologians, philosophers, and professors. ${ }^{31}$ They also discussed the similarities between the position of the donor, especially the hands, and the figure of Saint Francis in Saint Francis Receiving the Stigmata, a version of which belonged to Anselm Adornes (1424-1483). ${ }^{32}$ Ultimately, Neidhardt and Schölzel concluded that the donor could not be identified directly with the Adornes family of Bruges. They did not, however, note that the list of original signatories of the Giustiniani contract of 1347 included one Gabriele Adorno, which meant that less than a century earlier, a Genoese Adornes had, by contract, become a Giustiniani.

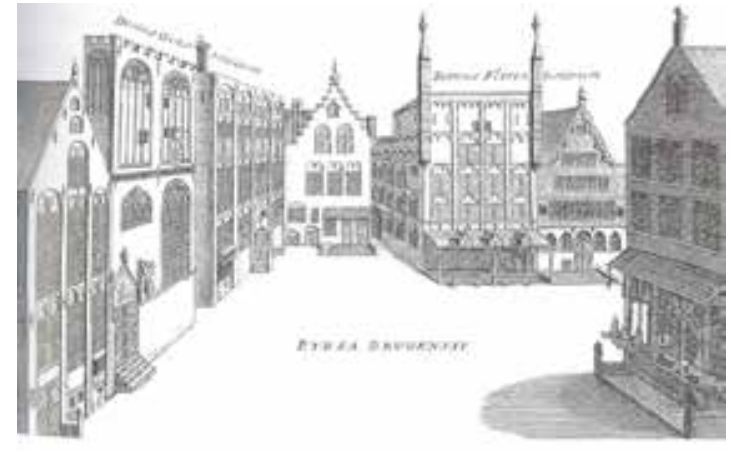

Fig. 4 Byrsa Brugensis, engraving, from Antonius Sanderus, Flandria Illustrata (Cologne, 1641). The bourse (Huize ter Buerze, established 1379) was situated at the top of the Vlamingstraat. The Genoese, Venetian, and Florentine communities established their trading houses in the vicinity (opposite and adjacent to the bourse).

13 Whether the successors to the signatories still considered themselves to be connected a century later is unclear. Undoubtedly, though, members of the Genoese community resident in Bruges would have maintained connections through the Genoese trading house on the Beursplein at Vlamingstraat 33 (fig. 4). The activities of Genoese traders who traveled between Genoa and the 
North Sea in semiannual convoys would have been administered from this location, as were those of Genoese residents of the city. Thus it is likely that this small, regionally defined group, who often sailed together on voyages lasting approximately fifty days, would have had at least a passing familiarity with one another, as well as with other members of the Genoese community in Bruges.

\section{The Archangel Michael}

14 An understanding of the origins of the Giustiniani family as a patrician trading society on Chios might help to unravel the association of the donor in the Dresden Triptych with Saint Michael. Traditionally, a representation of a saint would identify him or her as the namesake protector of the secular donor, but here the figure of Saint Michael might have broader significance. Saint Michael, together with Saint George, was emblematic of chivalry and the glorification of knighthood. He was also regarded as protector of all believers and, in the Eastern Orthodox Church, especially at Constantinople, he was considered "the great heavenly physician." ${ }^{33}$ Given the Giustiniani connection to Chios and their trade in mastic (the island's principal resource, known for its medicinal properties), perhaps the significance of this saint was linked to the Greek Orthodox tradition, rather than to the given name of the donor. The choice of Saint Michael might therefore be understood in the context of both the noble society that formed the basis of Giustiniani familial connections and the context of protection for a group that was collectively displaced, whether on Chios, in Bruges, or in Antwerp. ${ }^{34}$ It goes without saying that the representation of Saint Michael remains an obstacle to the identification of the donor as an individual who did not bear this name. However, this issue might be addressed through further enquiries that focus on contemporary Genoese merchants who sought the archangel's protection.

\section{Giustiniani and the Borromei Ledger for 1438}

15 Considerably more evidence than is currently available would be necessary to establish a sound relationship between the activities of the Giustiniani in Bruges in the late 1430s and a person with a role in the commissioning of the Dresden Triptych from van Eyck. The Michele Giustiniani identified by Weiss had apparently returned to Genoa after 1430, and until now, no evidence had come to light for any member of the family who resided in Bruges at roughly the time that the triptych was completed. For this reason, the reference to Raffaello Giustiniani in the Borromei ledger, as the one member of the family located in Bruges in the late 1430s, is worthy of investigation. $^{35}$

16 The Borromei-Bruges accounts for Giustiniani transactions carry over from 1437, a tense period in Bruges given the impact of the sanctions imposed by the duke in the wake of a revolt the year before ${ }^{36}$ By mid-1437, if not earlier, foreign merchants who had customarily been based in Bruges are thought to have transferred many of their activities to Antwerp, Middelburg, or London to protect their financial interests. ${ }^{37}$ The 1438 ledger records activities from January 1 through the Antwerp spring fair and into the autumn of 1438. Recorded transactions include the names of Giustiniani family members involved in delivering or collecting goods, probably quantities of cloth but also oil. Among them is Antonio Giustiniani of Genoa, who was a ship owner, ${ }^{38}$ as well as Agostino, Amerigo, Damiano, Domenico, Francesco, Giannino, Niccoló, and Simone, all thought to have been based in Genoa. Only Raffaello is identified as being based in Flanders, a status confirmed by one reference to him as Raffaello Giustiniani "of Bruges." 39 
17 The Borromei current account for Raffaello Giustiniani begins on January 1, 1438, with a debit of

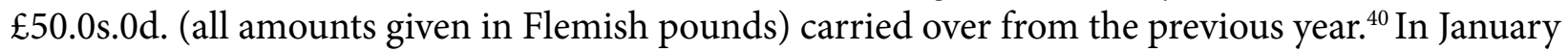
and February, Raffaello was writing letters from Middelburg (rather than Bruges) and receiving payments there. ${ }^{41}$ At Middelburg in February 1438, he issued a bill of exchange to the deliverers of goods from Seville and from the papal court on behalf of Domenico Giustiniani and one Beldesino Maruffo. ${ }^{42}$ By June, he had paid a sum into the Borromei Antwerp account, presumably after the Whitsun fair, ${ }^{43}$ and in July he settled an account between Jacopo and Girolamo Lomellino. ${ }^{44}$ In July and August, Raffaello accepted deliveries from Francesco de' Fornari of Genoa for Giovanni Ventura and Company of Barcelona and Avignon, ${ }^{45}$ and between June and December, he acted as "deliverer" of goods either to the bank itself, or to the bank and Ricci and Company of Avignon on behalf of Domenico Giustiniani. ${ }^{46}$ Finally, in December he paid a substantial sum (£20.0s.0d.) into the Borromei bank on behalf of Cristofano Cattano, their agent at Southampton, who was a major supplier of pigments. ${ }^{47}$

18 During the course of 1438, the turnover in the Borromei account of Raffaello Giustiniani amounted to $£ 1,213.12 \mathrm{~s} .1 \mathrm{~d}$., and at the end of the year a credit of $£ 10.0$ s. $5 \mathrm{~d}$. was carried forward to the ledger for the following year. Raffaello also maintained a separate joint account with Girolamo Lomellino, with a turnover of a further $£ 100.0 \mathrm{~s} .0 \mathrm{~d} .{ }^{48}$ This made him one of the Borromei bank's more important clients. The ledger entries show that he acted as a conduit for funds being transferred to Bruges by bills of exchange, presumably to pay for goods to export. ${ }^{49}$ Funds are also shown being transferred from Bruges, mainly to Genoa to other members of the family, as well as to Seville, Barcelona, Avignon, London, and to the papal court, which was then resident in Bologna. There can be little doubt that Raffaello was resident in Bruges as the agent of the Giustiniani family in Genoa and that he traded for them and for himself on the markets in Bruges, Antwerp, and Middelburg. The financial dealings of Raffaello Giustiniani in 1438 offer the most substantial evidence currently available for a member of the family situated in the Burgundian Netherlands during the period when the triptych was commissioned from van Eyck.

\section{A Traveling Altarpiece}

19 This evidence is significant in a broader sense, shifting the focus from the donor as an individual to the more general context for commissioning a work of art in Bruges in the late 1430s. In size and construction, the triptych was ideally suited for a mobile patron, for use in temporary lodgings, such as those occupied by a merchant. As a matter of tradition, Bruges merchants shifted their activities to Antwerp during the annual Pinxstenmarkt, the Whitsun fair, which lasted for six weeks. However, after the uprising in May 1437, the ducal court and city officials evacuated Bruges, and many merchants are thought to have retained temporary residences elsewhere, perhaps until the late spring or summer of $1438 .{ }^{50}$ Available evidence also suggests that mercantile activities in Bruges were severely disrupted during the Anglo-Burgundian conflict, which reached crisis point in the years after the Peace of Arras in 1435. This has led to theories that the foreign merchant communities stayed away from Bruges altogether until negotiations with the duke encouraged their return. ${ }^{51}$

20 Something that would help to support the argument that the Dresden Triptych was a privately owned, portable altarpiece would be evidence of a papal privilege. Recent research by Diana Webb suggests that portable altarpieces became increasingly common from the thirteenth cen- 
tury onward, when more frequent grants for their possession were made by the pope. ${ }^{52}$ In the ten years of his pontificate (1342-52) Pope Clement VI granted licenses for portable altars to some 150 individuals in England alone. ${ }^{53} \mathrm{~A}$ few of the grantees, who included the king and members of the highest nobility (Henry, count and later duke of Lancaster), a knight, a squire, and citizens of London and Lincoln, were also licensed to hear mass at daybreak or to have it celebrated privately in places under interdict. It goes without saying that evidence of a papal privilege to own the Dresden Triptych or other contemporary portable altars could offer a valuable point of reference. Perhaps more digging in the supplications housed in the Vatican Archive could bear fruit, but in lieu of this, it is plausible to consider that a portable altarpiece painted for a member of the Giustiniani family could have been used in temporary lodgings in Middelburg or Antwerp.

21 If this was the case, and assuming that Jan van Eyck painted this portable altar in his Bruges workshop sometime in 1437, the texts on the frames take on new significance because they appear to be linked to Bruges itself. According to Carol Purtle, the texts suggest a specific relationship with the liturgy of the church of Saint Donatian in Bruges as a spiritual home. ${ }^{54}$ If the triptych was painted for Michele Giustiniani of Genoa, the texts might be read as a form of nostalgia. If it is associated with Raffaello or another member of the Giustiniani circle resident in Bruges, the texts might well reflect the donor's efforts to integrate into Bruges society in the manner achieved by the Adornes. Either way, the altarpiece would have provided the donor with a familiar location for his contemplation of the Virgin, wherever he found himself.

\section{Like a Book}

22 Issues of use and practicality in the format and surface treatment of the triptych would have been central to its conception and creation as a portable object. Its book format and the legibility of the Annunciation on the exterior wings have been compared to van Eyck's Madrid Annunciation (ca. 1437-38) by John Hand, Catherine Metzger, and Ron Spronk. ${ }^{55}$ They suggested that the undated Madrid diptych was produced soon after the Dresden Annunciation, with small but significant revisions. The shapes of the underdrawn pedestals closely resemble each other, but the bases in the Madrid version were extended over the lip of the lower member of the frame during the painting process, ostensibly to provide a greater sense of spatial perception from a particular vantage point. ${ }^{56}$

23 The framing devices chosen by van Eyck also point to the needs of a mobile client, who potentially packed the triptych in a small crate or carrying case for transport within the Burgundian Netherlands or to Genoa. The folding wings would have functioned as a protective barrier: when closed, they would ensure that the red lake garment of the Virgin would not come into contact with a cloth cover or packing material within a chest or crate. Like the draperies in van Eyck's Lucca Madonna and Van der Paele Madonna, and the under-dress of the Berlin Virgin and Child in a Church, the red-lake-containing paint would have required considerable time to dry. Depending on the precise makeup, thickness, and siccative content of the glaze layers, these could have been dry to the touch within several weeks, but a firm film would take much longer, possibly a month but perhaps as long as a year.

24 Furthermore, in order that the Annunciation on the Dresden exterior wings could withstand bumps and movement, the upper and lower moldings of the wing frames for both inner and 
outer images were constructed in a single piece, with deep recesses on both sides. ${ }^{58}$ The semi-integral frame could thus bear much more weight and stress. The paint on the exterior frames was apparently damaged while they were fulfilling their original protective function, because in the sixteenth or seventeenth century a faux turtle-shell design, imitating the then-fashionable veneer, replaced the earlier scheme of jaspered paint..$^{59}$ The book format can thus be thought of as serving an important function, protecting the images within during transport, while the frame would lend additional stability to the panels. Like the jaspered sides and reverse found on van Eyck's Saint Barbara, the Portrait of Margaret van Eyck and other contemporary works, the jaspering was meant to be seen, but its speckled appearance also camouflaged wear and tear.

\section{Conclusion}

25 The question of whether Raffaello Giustiniani commissioned the Dresden Triptych for Michele Giustiniani, for a member of his circle, or for himself may never be answered satisfactorily: neither the name given in the Borromei ledger, the structure of the triptych, nor its surface treatment offers sufficient information to identify the donor depicted by van Eyck in 1437. The new evidence is perhaps more significant in a larger sense, pointing as it does to the financial dealings of the Giustiniani family, who like other Italian merchants, appear to have shifted their activities to Middelburg and Antwerp between 1437 and 1439. Thus, the evidence in the Borromei ledger, in context with contemporary events, points to circumstances that would have been more challenging for commissioning a work of art from Jan van Eyck than have been previously acknowledged.

\section{Acknowledgements}

Special thanks are due to James Bolton, Queen Mary, University of London, Libby Sheldon, University College London, and Christoph Schölzel, Gemäldegalerie Alte Meister, Dresden. The bulk of the research from which this paper is drawn was funded by the Arts and Humanities Research Council of Great Britain.

Noëlle Streeton is Associate Professor for Conservation Science at the University of Oslo. Until 2008 she was based at University College London, where she completed an MA in Conservation before undertaking PhD research under Libby Sheldon (Department of History of Art, Materials Studies). Her thesis considers the workshop practices of Jan van Eyck and the potential relationship between his painting technique, the availability of artists' materials and changes in the Burgundian economy in the 1420 s and 30 s. Her larger research interests extend to the uses of conservation documentation and analytical data on pigments and paint systems to contribute to more accurate historical accounts of painting and workshop practice in Northern Europe during the late medieval period.

\section{List of Illustrations}

Fig. 1 Jan van Eyck, Virgin and Child with Saints Catherine and Michael and a Donor (the Dresden or Giustiniani Triptych), 1437, oil on oak panel, 33.1 x $27.5 \mathrm{~cm}$ (center panel), $33.3 \times 13.6 \mathrm{~cm}$ (wings). Staatliche Kunstsammlungen, Dresden, Gemäldegalerie Alte Meister, inv. no. 799 (artwork in the public domain) 
Fig. 2 The Dresden Triptych shown closed, displaying The Annunciation on the exterior of the wings.

Fig. 3 A coat of arms was painted onto the upper corner of each wing frame. Hugo Bürkner's drawings (far left top and bottom) are shown here alongside Christoph Schölzel's recent macrophotographs and scale drawings (see Bürkner, Die Dresdener Gemälde-Gallerie, and Schölzel's drawings in Neidhardt and Schölzel,Das Geheimnis des Jan van Eyck, p. 180).

Fig. 4 Byrsa Brugensis, engraving, from Antonius Sanderus, Flandria Illustrata (Cologne, 1641). The bourse (Huize ter Buerze, established 1379) was situated at the top of the Vlamingstraat. The Genoese, Venetian, and Florentine communities established their trading houses in the vicinity (opposite and adjacent to the bourse).

${ }^{1}$ U. Neidhardt and C. Schölzel, "Jan van Eycks Dresdener Marientriptychon - Entstehung und Funktion," in Das Geheimnis des Jan van Eyck: Die frühen niederländischen Zeichnungen und Gemälde in Dresden, ed. T. Ketelsen and U. Neidhardt (Dresden: Staatliche Kunstsammlungen, 2005), pp. 14-15.

${ }^{2}$ U. Neidhardt and C. Schölzel, "Jan van Eyck's Dresden Triptych," in Investigating Jan van Eyck, eds. S. Foister, S. Jones, and D. Cool (Turnhout: Brepols, 2000), p. 37; Neidhardt and Schölzel, "Jan van Eycks Dresdener Marientriptychon," pp. 20-21; Das Geheimnis des Jan van Eyck, p. 180. ${ }^{3}$ Neidhardt and Schölzel, "Jan van Eyck's Dresden Triptych,"p. 37; Neidhardt and Schölzel, "Jan van Eycks Dresdener Marientriptychon,"pp. 20-21.

${ }^{4}$ S. Nash, Northern Renaissance Art (Oxford and New York: Oxford University Press, 2008), pp. 11-24, gives the most recent discussion of the historiographic challenges posed by the dispersal and destruction of Netherlandish art and archival evidence.

${ }^{5}$ Filippo Borromei and Company of Bruges (1438), libri mastri 8, Borromeo-Arese family archive, Archivio Borromeo dell' Isola Bella (ABIB), http://www.queenmaryhistoricalresearch.org/default. aspx (accessed March 2010). James Bolton and Francesco Guidi Bruscoli established the Borromei Bank Research Project, Queen Mary, University of London. Their database has been developed with an award from the Economic and Social Research Council of Great Britain and two grants from the Westfield Trust. The surviving ledgers of Filippo Borromei and Company of Bruges for 1438 (BBr), and of Filippo Borromei and Company of London for the years 1436-39 are held in the Borromeo-Arese family archive at the Palazzo Borromeo on Isola Bella (Archivio Borromeo dell' Isola Bella [ABIB], libri mastri 7 (London) and 8 (Bruges). Permission to use these and other ledgers has been granted by the family to Professor Bolton.

${ }^{6}$ BBr f. 193.2, account of Ricci, Bernardo and Matteo \& Co., of Avignon, August 25, 1438, 3Box, 31.4.10 Cr; BBr f. 87.2, account of Raffaello Giustiniani, August 25, 1438, 3Box, 31.4.10 Dr.

${ }^{7}$ The topic of this article is addressed comprehensively in N. L. W Streeton, "Painting in Bruges in the Early Fifteenth Century: Investigations of the Technique of Jan van Eyck and Imported Artists' Materials with an Evaluation of Methods for Technical Art History," PhD thesis, University College, London, 2011. See also N. Streeton, “The Impact of the Pigment Trade on the Palette of 
Jan van Eyck," Object: Graduate Research and Reviews in the History of Art and Visual Culture 10 (2007/08): 81-108.

${ }^{8}$ H. Gronau, "Zur Geschichte des van Eyckschen Flügelältarchens in der Dresdener Galerie," Kunstchronik 27 (1916): 445 (cited in Neidhardt and Schölzel, "Jan van Eyck's Dresden Triptych," p. 27 nn. 5 and 6, and p. 34, and in Neidhardt and Schölzel, "Jan van Eycks Dresdener Marientriptychon," p. 14).

${ }^{9}$ A. Hirt, Kunstbemerkungen auf einer Reise über Wittenberg und Meißen nach Dresden und Prag (Berlin: Duncker und Humblot, 1830); M. J. Friedländer, Early Netherlandish Painting, vol. 1, The Van Eycks - Petrus Christus, 2nd ed., trans. H. Norden, ed. N. Veronee-Verhaegen (Leiden and Brussels: A. W. Sijthoff and Éditions de la Connaissance, 1967), p. 62.

${ }^{10}$ Dresden inventory 1754, no. 392 (cited in Neidhardt and Schölzel, "Jan van Eyck's Dresden Triptych,"pp. 28, 34, and in Neidhardt and Schölzel, "Jan van Eycks Dresdener Marientriptychon,"pp. 14-15 n. 9).

${ }^{11}$ Neidhardt and Schölzel, “Jan van Eyck's Dresden Triptych,"p. 27 nn. 5 and 6, and p. 34;Neidhardt and Schölzel, "Jan van Eycks Dresdener Marientriptychon,"p. 14.

${ }^{12}$ C. J. Purtle, The Marian Paintings of Jan van Eyck (Princeton, N.J.: Princeton University Press, 1982), pp. 128-29.

${ }^{13}$ Purtle, Marian Paintings, pp. 128-30; C. Harbison, Jan van Eyck: The Play of Realism London: Reaktion Books, 1991), p. 25 and fig. 5; Neidhardt and Schölzel, "Jan van Eyck's Dresden Triptych,"p. 38 n. 3.

${ }^{14}$ H. L. F. H. Bürkner, Die Dresdener Gemälde-Gallerie: Original-Radierungen von Prof. H. Bürkner (Dresden: Gemäldegalerie, 1863).

${ }^{15}$ L. Kaemmerer, Hubert und Jan van Eyck (Bielefeld and Leipzig: Verlag von Velhagen und Klafing, 1898), pp. 78-84; W. H. J. Weale with M. W. Brockwell, The Van Eycks and Their Art (London: John Lane, 1912), p. 82; G. Künstler, "Jan van Eyck's Wahlwort 'Als ich can' und de Flügelaltärchen in Dresden," Wiener Jahrbuch für Kunstgeschichte25 (1972): 107-27.

${ }^{16}$ A. Schmarsow, Hubert und Jan van Eyck (Leipzig: Hiersemann, 1924), pp. 129-31.

${ }^{17}$ Author's translation from Schmarsow, van Eyck, p. 130: "ein Michele Giustiniani ist in Genua urkundlich seit Anfang des Jahrhunderts überliefert."

${ }^{18}$ Archivio di Stato, Genoa, MS 521, p. 1163 (cited in R. Weiss, "Jan van Eyck and the Italians," Italian Studies 11 [1956]: 2 n. 7). See also C. Desimoni and L. T. Belgrano, "Documenti ed estratti inediti o poco noti riguardanti la storia del commercio e della marina ligure: Brabante, Fiandra e Borgogna," Atti della società ligure di storia patria 5 (1867): 391, 393, 407, 415; and R. Doehaerd and C. Kerremans, Les Relations commerciales entre Gênes, la Belgique et loutrement d'apres les archives notariales gênoises, 1400-1440, vol. 5 of Études d'histoire économique et sociale(Brussels and Rome: Institut Historique Belge de Rome,1952), e.g., pp. 612-636 (nos. 787-803).

${ }^{19}$ Weiss, Italian Studies, p. 2.

${ }^{20}$ H. Menz, "Zur Freilegung einer Inschrift auf dem Eyck-Altar der Dresdener Gemäldegalerie,"Jahrbuch der Staatlichen Kunstsammlungen Dresden(1959):2, 28-29 n. 1: "Die Aufnahmen waren von Dr Hilde Krauth, Berlin, im Herbst 1959 hergestellt worden."See below for further discussion. ${ }^{21}$ Friedländer, Early Netherlandish Painting, p. 62.

${ }^{22}$ Menz, Jahrbuch, pp. 2, 28-29 n. 1; A. Mayer-Meintschel, Niederländische Malerei 15. und 16. Jahrhundert: Katalog der Gemäldegalerie Alte Meister (Dresden: Gemäldegalerie, 1966), p. 29.

${ }^{23}$ Neidhardt and Schölzel, "Jan van Eyck’s Dresden Triptych,"p. 38 n. 3. 
${ }^{24}$ Neidhardt and Schölzel, “Jan van Eyck’s Dresden Triptych,"pp. 27-34; Das Geheimnisdes Jan van Eyck, p. 180.

${ }^{25}$ Neidhardt andSchölzel, “Jan van Eyck’s Dresden Triptych,"pp. 27-34; Das Geheimnis des Jan van Eyck, p. 180. Note: investigation using a nondestructive analytical method (e.g., confocal microscopy or an optical-sampling technique using laser technology) could help to resolve this point. ${ }^{26}$ James Bolton, Queen Mary, University of London, unpublished typescript, n.d.

${ }^{27}$ A. Waksman, "Les Giustiniani: Une saga Méditerranéenne," Orizonti television documentary, Vision Internationale Corsica and France 3 Corse, aired May 10, 2008: http://corse.france3.fr/ emissions/19230432-fr.php\#\#para44256076 (accessed June 24, 2008); E. Giustiniani, “The Story of a Noble Genoese Family that Formed a Dynasty on the Island of Chios in the Aegean": http:// www.levantine.plus.com/testi56.htm (accessed June 24, 2008).

${ }^{28}$ See K. Fleet, European and Islamic Trade in the Early Ottoman State: The Merchants of Genoa and Turkey (Cambridge: Cambridge University Press, 1999); Waksman, "Les Giustiniani." 29 "Compagniam de pecunia non faciam cum aliquo habitante ultra Vultabium et Savignonem et Montem altum, neque ultra Varaginem": "Leges Genuenses, 1347," in Giustiniani, “The Story"; Waksman, "Les Giustiniani."

${ }^{30}$ Neidhardt and Schölzel, "Jan van Eyck's Dresden Triptych," pp. 36-37; N. Geirnaert, "Anselm Adornes and His Daughters: Owners of Two Paintings of Saint Francis by Jan van Eyck?," in Investigating Jan van Eyck, p. 165.

${ }^{31}$ J. Rotsaert, "De schenker van Jan van Eycks dresdens reisaltaartje geïdentificeerd," unpublished MS, 1983 (cited in Neidhardt and Schölzel, "Jan van Eyck's Dresden Triptych," pp. 36-39 n. 18).

${ }^{32}$ Giernaert, "Anselm Adornes,"pp. 163-68.

${ }^{33}$ R. Guiley, The Encyclopedia of Angels (New York: Checkmark Books, 1996), pp. 128-29.

${ }^{34}$ B. Z. Kedar, Merchants in Crisis: Genoese and Venetian Men of Affairs and the Fourteenth-Century Depression (New Haven, Conn.: Yale University Press, 1976), pp. 97-102; G. W. Day, "Review of Merchants in Crisis: Genoese and Venetian Men of Affairs and the Fourteenth-Century Depression (by Benjamin Z. Kedar, New Haven: Yale University Press, 1976)," Journal of Economic History 37, no. 4 (1977): 1070.

${ }^{35} \mathrm{BBr}$ f. 193.2.

${ }^{36}$ J. van Dixmude, Laetste deel der kronyk, ed. J. J. de Smet, vol. 3, pp. 76-80, Recueil des chroniques de Flandre (Brussels: Commission royale d'histoire, 1856); J. Munro, Wool, Cloth and Gold: The Struggle for Bullion in Anglo-Burgundian Trade, 1340-1478(Brussels and Toronto: Editions de l'Université de Bruxelles and University of Toronto Press, 1972), p. 114 n. 69; J. Dumolyn, De Brugse opstand van 1436-1438, Standen en Landen 101 (Kortrijk-Heule: Nationaal Centrum voor Navorsing, 1997), pp. 73, 231-48; W. Blockmans and W. Prevenier, The Promised Lands: The Low Countries Under Burgundian Rule, 1369-1530, trans. E. Fackelman, ed. E. Peters (Philadelphia: University of Pennsylvania Press, 1999), pp. 85, 159-63; R. Vaughan, Philip the Good: The Apogee of Burgundy (Woodbridge, Suffolk, UK: Boydell Press, 2002),pp. 87-91.

${ }^{37}$ Dumolyn, De Brugse opstand, p. 73; Blockmans and Prevenier, Promised Lands, pp. 164-65; Vaughan, Philip the Good, pp. 86-92 n. 1.

${ }^{38} \mathrm{BBr}$ ff. 193.2; 87.2.

${ }^{39} \mathrm{BBr}$ ff. 193.2; 87.2.

${ }^{40} \mathrm{BBr}$ ff. $9.1 ; 114$.

${ }^{41} \mathrm{BBr}$ f. 9.1

${ }^{42} \mathrm{BBr}$ f. 9.1 . 
${ }^{43} \mathrm{BBr}$ f. 9.1.

${ }^{44} \mathrm{BBr}$ f. 88.7.

${ }^{45} \mathrm{BBr}$ ff. 87.2; 198.

${ }^{46} \mathrm{BBr}$ ff. $193.2 ; 9.1 ; 350.4 ; 142.4 ; 193$.

${ }^{47} \mathrm{BBr}$ ff. 142.4; 179. Genoese merchants who dealt in pigments are discussed in Streeton, "Merchants, Pigments and Panels" and N. Streeton, "Importing Colour: Merchants, Painters and the Status of Imported Pigments in the Late-medieval North," paper presented at the symposium "Revealing Medieval and Renaissance Europe: Makers and Markets 1100-1600," held at the Victoria \& Albert Museum, London, February 18-20, 2010.

${ }^{48} \mathrm{BBr}$ ff. 9.1; $17.2 ; 87.2 ; 88.7 ; 142.4 ; 179.1 ; 193.2 ; 198.1$.

49 Thanks to Professor James Bolton for his discussions on this topic.

${ }^{50}$ Dumolyn, De Brugse opstand, p. 165; Vaughan,Philip the Good, pp. 87-92, 169-70, 245; Munro, Wool, Cloth and Gold, p. $118 \mathrm{nn} .86$ and 87. The Calendar of the Patent Rolls refers to the conference at Calais in 1438-39, which aimed to reach some sort of commercial peace between England and Burgundy. An accord was signed, but these negotiations were largely unsuccessful, and in 1441 commissioners from the Low Countries were sent to England to discuss a commercial treaty. See Calendar of the Patent Rolls, Preserved in the Public Record Office...Henry VI, Vol. III. A.D. 1436-1441 (London: His Majesty's Stationery Office, 1907), pp. 84, 146.

${ }^{51}$ Dumolyn, De Brugse opstand, p. 73; Vaughan, Philip the Good, pp. 86, 91 n. 1.

${ }^{52}$ D. Webb, "Domestic Space and Devotion," in Defining the Holy, eds. A. Spicer and S. Hamilton (Aldershot, UK: Ashgate, 2005), pp. 36-37.

${ }^{53}$ Calendars of Entries in the Papal Registers Relating to Great Britain and Ireland, ed. W. H. Bliss et al. (London, 1893).

${ }^{54}$ Neidhardt and Schölzel, “Jan van Eyck’s Dresden Triptych”, pp. 26-27.

${ }^{55}$ J. O. Hand, C. A. Metzger, and R. Spronk, Prayers and Portraits: Unfolding the Netherlandish Diptych, exh. cat., National Gallery of Art, Washington, D.C., and Koninklijk Museum voor Schone Kunsten, Antwerp, in association with Harvard University Art Museums, Cambridge, Mass. (London and New Haven: Yale University Press, 2006), p. 74.

${ }^{56}$ Hand, Metzger, and Spronk, Prayers and Portraits, p. 74.

${ }^{57}$ D. Erhardt, C. S. Tumosa, and M. F. Mecklenburg, "Long-term Chemical and Physical Processes in Oil Paint Films," Studies in Conservation 50, no. 2 (2005): 143, 147; M. F. Mecklenburg, unpublished report, May 2007; and N. Streeton, unpublished experimental results, May-August 2007 (author files).

${ }^{58}$ Neidhardt and Schölzel, "Jan van Eycks Dresdener Marientriptychon," p. 15.

${ }^{59}$ Correspondence dated October 10, 1984 between van Asperen de Boer and Prof. Dr. H. P. Schramm (Dresden, Gemäldegalerie, Conservation Department files); J. R. J. van Asperen de Boer sample report A234/1, February 1982 (private files of J. R. J. van Asperen de Boer).

\section{Bibliography \\ Original Sources}

Borromei Bruges ledgers: Filippo Borromei and Company of Bruges (1438), libri mastri 8, Borromeo-Arese family archive, Archivio Borromeo dell' Isola Bella (ABIB): http://www.queenmaryhistoricalresearch.org/default.aspx (accessed November 2008). 
Calendars of Entries in the Papal Registers Relating to Great Britain and Ireland. Edited by W. H. Bliss et al. London, 1893.

Calendar of the Patent Rolls, Preserved in the Public Record Office...Henry VI, Vol. III. A.D. 14361441. London: His Majesty's Stationery Office, 1907.

van Dixmude, J. Laetste deel der kronyk, edited by J. J. de Smet, vol. 3, pp. 30-109. Recueil des chroniques de Flandre. Brussels: Commission royale d'histoire, 1856.

Doehaerd, R., and C. Kerremans. Les Relations commerciales entre Gênes, la Belgique et l'outrement d'apres les archives notariales gênoises, 1400-1440. Vol. 5 of Études d'histoire économique et sociale. Brussels and Rome: Institut Historique Belge de Rome, 1952.

\section{Secondary Sources}

Blockmans, W., and W. Prevenier. The Promised Lands: The Low Countries Under Burgundian Rule, 1369-1530. Translated by E. Fackelman. Edited by E. Peters. Philadelphia: University of Pennsylvania Press, 1999.

Bürkner, H. L. F. H. Die Dresdener Gemälde-Gallerie: Original-Radierungen von Prof. H. Bürkner. Dresden: Gemäldegalerie, 1863.

Day, G. W. "Review of Merchants in Crisis: Genoese and Venetian Men of Affairs and the Fourteenth-Century Depression (by Benjamin Z. Kedar, New Haven: Yale University Press, 1976)." Journal of Economic History37, no. 4 (1977): 1070-71. doi:10.1017/S0022050700095061

Desimoni, C., and L. T. Belgrano. "Documenti ed estratti inediti o poco noti riguardanti la storia del commercio e della marina ligure: Brabante, Fiandra e Borgogna." Atti della società ligure di storia patria 5 (1867).

Dumolyn, J. De Brugse opstand van 1436-1438. Standen en Landen 101. Kortrijk-Heule: Nationaal Centrum voor Navorsing, 1997.

Erhardt, D., C. S. Tumosa, and M. F. Mecklenburg. "Long-term Chemical and Physical Processes in Oil Paint Films." Studies in Conservation 50, no. 2 (2005): 143-50.

Fleet, K. European and Islamic Trade in the Early Ottoman State: The Merchants of Genoa and Turkey. Cambridge: Cambridge University Press, 1999.

Friedländer, M. J. Early Netherlandish Painting. Vol. 1.,The Van Eycks - Petrus Christus. 2nd ed. Translated by H. Norden. Edited by N. Veronee-Verhaegen. Leiden and Brussels: A. W. Sijthoff and Éditions de la Connaissance, 1967.

Geirnaert, N. "Anselm Adornes and His Daughters: Owners of Two Paintings of Saint Francis by Jan van Eyck?" In Investigating Jan van Eyck, eds. S. Foister, S. Jones, and D. Cool, pp. 163-68. Turnhout: Brepols, 2000. 
Giustiniani, E. “The Story of a Noble Genoese Family that Formed a Dynasty on the Island of Chios in the Aegean.": http://www.levantine. plus.com/testi56.htm (accessed June 24, 2008).

Gronau, H. “Zur Geschichte des van Eyckschen Flügelältarchens in der Dresdener Galerie.” Kunstchronik27 (1916): 445.

Guiley, R. The Encyclopedia of Angels. New York: Checkmark Books, 1996.

Hand, J. O., C. A. Metzger, and R. Spronk. Prayers and Portraits: Unfolding the Netherlandish Diptych. Exh. cat. National Gallery of Art, Washington, D.C., and Koninklijk Museum voor Schone Kunsten, Antwerp, in association with Harvard University Art Museums, Cambridge, Mass. New Haven and London: Yale University Press, 2006.

Harbison, C. Jan van Eyck: The Play of Realism. London: Reaktion Books, 1991.

Hirt, A. Kunstbemerkungen auf einer Reise über Wittenberg und Meißen nach Dresden und Prag. Berlin: Duncker und Humblot, 1830.

Kaemmerer, L. Hubert und Jan van Eyck. Bielefeld and Leipzig: Verlag von Velhagen und Klafing, 1898.

Kedar, B. Z. Merchants in Crisis: Genoese and Venetian Men of Affairs and the Fourteenth-Century Depression. New Haven: Yale University Press, 1976.

Ketelsen, T., and U. Neidhardt, U.Das Geheimnis des Jan van Eyck: Die frühen niederländischen Zeichnungen und Gemälde in Dresden. Dresden: Staatliche Kunstsammlungen, 2005.

Künstler, G. “Jan van Eyck’s Wahlwort 'Als ich can' und de Flügelaltärchen in Dresden.” Wiener Jahrbuch für Kunstgeschichte 25 (1972): 107-27.

Mayer-Meintschel, A. Niederländische Malerei 15. und 16. Jahrhundert: Katalog der Gemäldegalerie Alte Meister. Dresden: Gemäldegalerie, 1966.

Menz, H. “Zur Freilegung einer Inschrift auf dem Eyck-Altar der Dresdener Gemäldegalerie."Jahrbuch der Staatlichen Kunstsammlungen Dresden(1959): 2, 28-29.

Munro, J. Wool, Cloth and Gold: The Struggle for Bullion in Anglo-Burgundian Trade, 1340-1478. Brussels and Toronto: Editions de l'Université de Bruxelles and University of Toronto Press, 1972.

Nash, S. Northern Renaissance Art. Oxford and New York: Oxford University Press, 2008.

Neidhardt, U., and C. Schölzel. "Jan van Eyck’s Dresden Triptych." In Investigating Jan van Eyck, eds. S. Foister, S. Jones, and D. Cool, pp. 25-39. Turnhout; Brepols, 2000. 
Neidhardt, U., and C. Schölzel. "Jan van Eycks Dresdener Marientriptychon - Entstehung und Funktion." In Das Geheimnis des Jan van Eyck: Die frühen niederländischen Zeichnungen und Gemälde in Dresden, eds. T. Ketelsen and U. Neidhardt, pp. 14-21. Dresden: Staatliche Kunstsammlungen, 2005.

Purtle, C. J. The Marian Paintings of Jan van Eyck.Princeton, N.J.: Princeton University Press, 1982.

Schmarsow, A. Hubert und Jan van Eyck. Leipzig: Hiersemann, 1924.

Streeton, N. "The Impact of the Pigment Trade on the Palette of Jan van Eyck." Object: Graduate Research and Reviews in the History of Art and Visual Culture 10 (2007/08): 81-108.

Streeton, N. "Importing Colour: Merchants, Painters and the Status of Imported Pigments in the Late-medieval North." Paper presented at the symposium "Revealing Medieval and Renaissance Europe: Makers and Markets 1100-1600," held at the Victoria \& Albert Museum, London, February 18-20, 2010 (unpublished typescript).

Streeton, N. L. W. "Painting in Bruges in the Early Fifteenth Century: Investigations of the Technique of Jan van Eyck and Imported Artists' Materials with an Evaluation of Methods for Technical Art History." PhD thesis, University College, London, 2011.

Vaughan, R. Philip the Good: The Apogee of Burgundy. Woodbridge, Suffolk, UK: Boydell Press, 2002 .

Waksman, A.“Les Giustiniani: Une saga Méditerranéenne." Orizonti television documentary. Vision Internationale Corsica and France 3 Corse, aired May 10, 2008: http://corse.france3.fr/ emissions/19230432-fr.php\#para44256076 (accessed June 24, 2008).

Weale, W. H. J., with M. W. Brockwell.The Van Eycks and Their Art. London: John Lane, 1912.

Webb, D. "Domestic Space and Devotion." In Defining the Holy, eds. A. Spicer and S. Hamilton, pp. 27-47. Aldershot, UK: Ashgate, 2005.

Weiss, R. “Jan van Eyck and the Italians." Italian Studies 11 (1956): 1-15.

\section{Recommended Citation:}

Noëlle L.W. Streeton, "Jan van Eyck's Dresden Triptych: New Evidence for the Giustiniani of Genoa in the Borromei Ledger for Bruges, 1438," JHNA 3:1 (Winter 2011), D0l: 10.5092/jhna.2011.3.1.1 